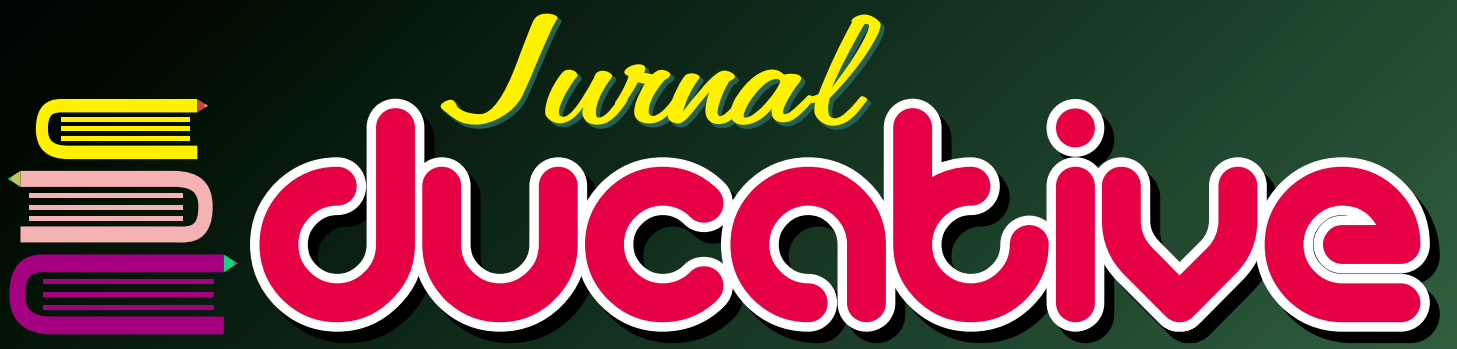 Journal of Educational Studies
}

Pengembangan Bahan Ajar Menulis Ringkasan dan Ikhtisar pada Mata Kuliah Pengembangan Keterampilan Menulis FKIP Universitas Baturaja Muhamad Doni Sanjaya, Muhamad Rama Sanjaya Upaya Meningkatkan Kemampuan Guru Menerapkan Penggunaan Bahan Ajar di SMA Negeri 3 Ogan Komering Ulu Aryanti Agustina

The Islamic Education Strategies Inlocal Culture Perspective of West Sumatera Society

Zulfani Sesmiarni, Junaidi, Darul Ilmi, Wedra Aprison

Problems In Learning Reading

(Case Study: Islamic Banking Students of IAIN Bukittinggi) Widya Syafitri

Teori Laactract dalam Persahabatan Generasi Millenial Qolbi Khoiri

e-Modul Computer Based Learning sebagai e-Resource Digital Literacy bagi Mahasiswa

Novrianti, Nofri Hendri, Ulfia Rahmi

Pengembangan Media Pembelajaran Mobile Learning berbasis Android Pada Mata Kuliah Kecerdasan Buatan Agus Nur Khomarudin, Liza Efriyanti

Meningkatkan Hasil Belajar Siswa Menggunakan Model Make a Match pada Mata Pelajaran IPS Kelas IV di SDN 11 OKU Yelmi Yunarti 


\title{
PROBLEMS IN LEARNING READING (CASE STUDY: ISLAMIC BANKING STUDENTS OF IAIN BUKITTINGGI)
}

\author{
Widya Syafitri \\ Fakultas Ekonomi dan Bisnis Islam, LAIN Bukittinggi \\ E-mail:widyasyafitri260780@gmail.com
}

\author{
Diterima: 10 Februari $2018 \quad$ Direvisi :23 Mei $2018 \quad$ Diterbitkan : 30 Juni 2018
}

\begin{abstract}
This research was aimed at investigating students' reading problems, especially reading in ESP context for Islamic Banking of Economic and Business Faculty of I AIN Bukittinggi. It was developed with a descriptive qualitative research. The data was gotten through interview to the lecturer and questionnaire distributed to the student. The result of the research showed that reading problems in ESP context based on indicator were: The first, a few students had problems related to indicator Negative Expectations like problems in recalling information after reading. The second, some the students had problems with processing information. The third, a half students had problem about topic and genre, limited vocabulary knowledge, lack of familiarity with the subject matter, difficulty level of the text (readability), weak verbal reasoning. The last, most of the students got difficulty at lack of fluency point, use of language level, inadequate use of effective reading strategies.
\end{abstract}

Keywords: Reading problems, Islamic banking students, ESP

\begin{abstract}
Abstrak
Penelitian ini bertujuan untuk mengetahui masalah yang dihadapi mahasiswa prodi Perbankan Syariah Fakultas Ekonomi dan Bisnis Islam IAIN Bukittinggi, dalam mempelajari Reading berbasis ESP. Jenis penelitian ini deskriptif kualitatif. Perolehan data melalui wawancara dengan dosen Bahasa Inggris serta mendistribusikan angket kepada mahasiswa semester IV jurusan Perbankan Syariah. Hasil penelitian ini dipaparkan berdasarkan beberapa indicator. Yang pertama, beberapa siswa memiliki masalah terkait dengan indikator Ekspektasi Negatif seperti masalah dalam mengingat informasi setelah membaca. Yang kedua, masalah terkait dalam memproses informasi. Ketiga, sebagian siswa memiliki masalah tentang topik dan genre, pengetahuan kosakata yang terbatas, kurangnya keakraban dengan materi pelajaran, tingkat kesulitan teks (keterbacaan), penalaran verbal yang lemah. Dan yang terakhir, sebagian besar siswa kurang fasih, penggunaan tingkat bahasa, serta tidak memadainya penggunaan strategi membaca yang efektif.
\end{abstract}

Kata Kunci: Masalah membaca, Mahasiswa Perbankan Syariah, ESP

Introduction

To be success in life, in this globalization era, people need to be good readers. It will be hard for society to have their purposes without having reading ability. Since the beginning of this modern era, people around the world come into contacts to do business, to exchange information, to find better education, to visit other places for recreational reasons and many people also move to other countries.
For the students, reading is one of skills that should be mastered, because it is the way of students to get information from books or texts that is used to add their knowledge. In addition, reading can develop the imagination and cognitive ability. It will force and guide mind to think about something that is out of mind. Moreover, it helps to encourage the components of language such as vocabulary, spelling, comprehension, grammar and pronunciation. These components will help 
the students to be fluent and accurate in mastering English. Studies have proved that EFL students who read a lot will get English better than those who do not. ${ }^{1}$ For most of these learners, reading is the most important skill to be mastered in order to ensure success not only in learning English, but also in learning any content class where reading in English is required ${ }^{2}$.

The Islamic Banking students of IAIN Bukittinggi also learn reading in their English subject. They are expected to be able to read the text and also comprehend the text in their context. Because the lecturer will ask the students to write down the main idea of the text or answer the question based on the text related to Islamic banking and economic. But this is still difficult for them; many students can't construct the meaning from the text. Floris and Divina (2009) discovered The hardest reading skill was recognizing text organization $(72.5 \%)$. They predicted, it was caused that many Indonesian students were not trained to activate recognizing text organization after they read a passage. ${ }^{3}$ While, Nunan states that there are two main reasons that make the students read; the first is for pleasure and the second is for information ${ }^{4}$. It means that the reading is great process in getting information.

Since the teaching reading for Islamic Banking through authentic materials, Researcher found several problems. The first, some of the students have lack of technique vocabularies and difficult to comprehend reading text, it can be seen when their lecturer asked them what they read about. The last, some of students seemed un-motivated in

${ }^{1}$ Flora and Marsha, TEFLIN Journal, Volume 20, Number 1, February 2009.

2 David Nunan, Practical English Language Teaching, Singapure: Mc Grow Hill, 2003 p. 69

${ }^{3}$ Flora and Marsha, TEFLIN Journal, Volume 20, Number 1, February 2009.

4 David Nunan, Practical English Language Teaching: Young Learners,..., p.69 learning reading. As the effect, most of them became passive participant in learning reading.

Based on the explanation above, it seems reasonable to conduct a research about the problem found in learning reading for Islamic Banking students of IAIN Bukittinggi.

\section{Reading Comprehension}

Reading comprehension is the process of communication that involves students in getting information from the text. The students need to the read the text; they need the complex processes to achieve the goal of comprehension. As Anderson in Janette, et al defines, "Reading comprehension is a multicomponent, highly complex process that involves many interactions between readers and what they bring to the text (previous knowledge, strategy use) as well as variables related to the text itself (interest in text, understanding of text types)."

\section{Principles for Teaching Reading}

A good lecturer has to use some of principles in teaching reading at the classroom. According to Nunan, there are eight principles for teaching reading, ${ }^{5}$ as follow : 1). Exploiting the reader's background knowledge. Students' background knowledge benefits them in reading activity. The lecturer must exploit it because the background knowledge will relate with the comprehension of the students. Exploiting background knowledge of the students will improve the students' comprehension in reading. Carrell and Connor conclude that background knowledge will influence reading comprehension. ${ }^{6} ; 2$ ). Building a strong vocabulary base. Being able to build a strong vocabulary base means the lecturer will get success in teaching reading. Levine and Reves state that it is easier for the

5David Nunan, Practical English Language Teaching, Mc Graw Hill, 2003 p. 74-78

${ }^{6}$ Carrell and Connor in David Nunan, Practical

English Language Teaching, Mc Graw Hill, 2003 p. 74 
reader of academic texts to cope with special terminology than with general vocabulary. Thus, the lecturer has to build the basic of fundamental in reading a text that is vocabulary; 3). Teaching for comprehension. "Teaching the author is an excellent technique for the meaningful cognitive interaction with the text and for assisting the students in the process of constructing meaning from the text' (Beck, McKeown, Hamilton and Kucan, 1997).

Thus, the lecturer must use the strategy to make students' understanding. The students will be difficult to comprehend the text when the lecturer does not give them the explanation how to use the strategy. So, reading lecturer has to think over the strategy to teach reading comprehension. 1). Working on increasing reading rate. One of the difficulties in teaching reading is that even when the students can read, much of their reading is not fluent. Often, to increasing students rate, lecturer over emphasize accuracy which impedes fluency. The lecturer must work toward finding a balance between assisting students to improve their reading rate and developing reading comprehension skills. Thus focus on reader's independence on dictionary and focuses on fluency, not speed; 2). Teaching reading strategies. The definition in the oxford, the strategies are the tools for active, self-directed involvement that is necessary for developing communicative ability. Strategies are not a single event, but rather a creative sequence of events that learners actively use. ${ }^{7}$ To achieve the desired results, students need to learn how to use a range of reading strategies that match their purpose for reading. Teaching them how to do this should be a prime consideration in the reading classroom; 3). Encouraging readers to transform strategies into skills. Strategies can be defined as conscious actions that learners

\footnotetext{
7 Oxford (1996) in David Nunan,..., p. 76
}

take to achieve desired goals or objectives, while a skill is a strategy that has become automatic. As learners consciously learn and practice specific reading strategies, the strategies move from conscious to unconscious; from strategy to skill; 4). Building assessment and evaluation into a teaching. Assessing growth and development in reading skills from both a formal and an informal perspective requires time and training. Both quantitative and qualitative assessment can include in the reading classroom. Where quantitative means information from reading comprehension tests as well as reading rate data while qualitative is reading journal responses, reading interest surveys and responses to reading strategy. 5). Striving for continuous improvement as a reading lecturer. The good reading lecturer actively teaches students what to do. To succeed, you need more than classroom tips and techniques; you need to understand the nature of the reading process because just because you are a reader does not mean that you are prepared to be a lecturer of reading.

\section{Reading Models}

Reading models are mainly set to describe the way a reader uses to construct meaning from printed texts. To be able to teach reading, it is important to understand what happens when we read. These models aim to find out how readers translate prints into meanings. Nunan divides reading process into three categories: bottom-up models, topdown models, and interactive models. ${ }^{8}$ The description as follow : 1). Bottom-up Reading Model. It is a model in which TOP is the higher order mental and BOT'TOM as the physical text on the page. It is where meaning takes precedence over structure. This model is a reading model that emphasizes the written or printed text. It also emphasizes the ability to

8 David Nunan, Practical English Language Teaching, Mc Graw Hill, 2003 p. 70 
decode or put into sound what is seen in the text, decodes them to sound, recognizes words and decodes meanings. The problem can be faced is inability to decode, lack of experience with words, text or activities; 2). Top-down Model. Approaches emphasize the importance of these schemata, and the reader's contribution, over the incoming text. It emphasizes the written or printed text. Reading is driven by a process that results in meaning. A view of reading which is generally considered to be top down is that of Goodman "reading is psycholinguistic guessing game his approach has been most influential in research on the use of conceptual knowledge inference and background information in the reading process". ${ }^{9}$; 3). Interactive models. The interactive model attempts to make the valid insights of bottomup and top-down models work together. It can be said combination of Bottom-up and Top-down processes. A good reader is both good decoder and good interpreter of the text. It seeks the account for both of bottom-up and top-down processing. This model suggests that the reading process is initiated by formulating hypotheses about meaning and by decoding letters and words.

\section{Types of Reading}

Intensive Reading. Intensive study of reading texts can be a means of increasing learner's knowledge of language features and their control of reading strategies. It can also improve their comprehension skill. Intensive reading is used on shorter texts in order to extract specific information. It includes very close accurate reading for detail. Use intensive reading skill to grasp the details of a specific situation; 2). Extensive Reading. It is used to obtain a general understanding of a subject and includes reading longer texts for pleasure as well as business books. Extensive reading

\footnotetext{
9 Alderson J Charles, Assesing The Nature of Reading,p16-19
}

fits into the meaning meaning-focused input and influence development stands of a course, depending on the level of the books that the learners read. When the books contain only a few unknown vocabulary and grammar items, extensive reading provides the conditions for fluency development. ${ }^{10}$

\section{The Purpose of Reading}

Readers have a variety of purposes in reading activity. Like to search for simple information, to skim quickly, to learn from texts, to integrate information, to write, and so on. Whether you are reading for enjoyment, to gain factual or procedural knowledge, or to learn skills such as how to analyze poetry, being aware of the purpose for reading is an essential first step. ${ }^{11}$ Thus purpose of reading is very important for the learner in language learning. As stated by Nunan, Reading is the most important skill to master in order to ensure success not only in learning English, but also in learning any content class where reading in English is required. ${ }^{12}$ It is clear that either the second or the foreign language learner will be helped to develop their other language skill, such as: listening, speaking and writing, or the even the other subject where reading is English is offered in that subject.

\section{Problem in Reading Comprehension}

Some of problems in teaching and learning reading skill that are faced by learners, they are: $\left.{ }^{13} 1\right)$. Language; The readers look at the texts with longer words will be more difficult to understand than those with shorter ones. It means that if the students face the

49

10 Teaching English Learners Strategies and Methods P

11 Janette K.Klinger,Sharon Vaughn, and Alison Boardman, Teaching Reading Comprehension to Students with Learning Difficult, p 104

12 David Nunan, Practical English Language Teaching,.....,p.69

${ }^{13}$ Jeremy Harmer, The Pratical of English Language Teaching, Cambridge, p. 202-208 
situation, they will get difficult in absorbing what the meaning of the text is; 2). Topic and genre. The teaching of receptive skill sometimes will not go as the learners want to be, because of the inappropriate topic or unfamiliar genre they are dealing with and will not be interested in learning; 3). Comprehension Task. When the lecturer gives the task and chooses the comprehension tasks to do, sometimes that the kind of tasks is not helping the students to more understand the skill. It is more likely to be testing them. By testing they will not use appropriate way to accomplish the students' improvement in this skill; 4). Negative Expectations. Before the students were starting to learn the skill, they already have negative expectations. They have feeling that they are not going to understand the passage because it is bound to be too difficult and they will be frustrating and de- motivating.

In addition, Peter Westwood states that students' problem in reading comprehension can be caused by a variety of different factors, including those intrinsic to the individual and others related to insufficient instruction or to inappropriate materials. The eight most frequently mentioned causal factors are: ${ }^{14} 1$ ). Limited vocabulary knowledge. If a student has difficulty understanding what he or she is reading, it is worth considering whether there is a serious mismatch between the student's own knowledge of word meanings (expressive and listening vocabulary) and the words used in the text; 2). Lack of fluency. Fluency is very relates with reading. Carver states that there are high correlations between oral reading fluency and comprehension. ${ }^{15}$ It means that there are appears to be an optimum rates of

14 Peter, What Lecturers Need to Know about Reading and Writing Difficulties, (Australia: Press Acer), p. 33-37

15 Peter, What Lecturers Need to Know about Reading and Writing Difficulties, (Australia: Press Acer), p. 34 fluency in reading that allows for accurate processing of information; 3). Lack of familiarity with the subject matter. It is much easier to read with understanding if the reader already possesses some prior knowledge of the topic using the school textbook as the medium for first introducing new information to students is not usually the most effective method of delivery. It is better to provide information first by other means (e.g. video, posters, mini-lecture, discussion) to build firm background knowledge before students are expected to read about that theme in printed texts. This is particularly important for weaker readers; 4). Difficulty level of the text (readability). The difficulty level of text is a major factor influencing whether or not material can be read with understanding. A text that is complex in terms of concepts, vocabulary, sentence length and structure is difficult for readers to process; 5). Inadequate use of effective reading strategies. Unlike skilled readers, weaker readers do not approach the interpretation of text strategically. They tend not to know of, or use, strategies that would help them visualize, make connections, reflect, infer, predict, question and summaries; 6). Weak verbal reasoning. The ability to understand text, and particularly to go beyond the words on the page in order to make relevant connections among facts and to critique the ideas, reflects the operation of verbal reasoning. To some extent, the ability to reason is determined by an individual's level of intelligence; but guided reading activities in which a lecturer uses effective questioning to challenge students to think more deeply about the text they are reading are helpful in developing their ability to reason from the information given. Deliberately guiding students to make connections between new information in text and their existing bank of knowledge is beneficial; 7). Problems with processing information. In order to maintain the meaning of text as the sentences and 
paragraphs accumulate, a reader has to be able to keep relevant information within working memory and make necessary connections between ideas. Limited working memory is sometimes suggested as a causal factor in poor comprehension. It is known that individuals differ in their working-memory capacity, with some able to process and accommodate much more information than others; 8). Problems in recalling information after reading. Recall is dependent partly upon factors such as vividness and relevance of the information in the text; but it is also dependent upon a student giving adequate attention to the reading task and knowing that it is important to remember details. Recall is strongest when readers connect new information in the text to their previous knowledge and experience, and when they rehearse key points from the text.

\section{ESP (English for Specific Purpose) and Reading.}

Foundations of Reading in ESP (English for Specific Purpose)

1). Foundational Aspects. To get a better understanding of current perspective on and approaches to ESP and reading, it is useful to see where reading has come from as related to ESP. Like ESP itself, interest in reading began to shift in the 1970s. As peter Stevens commented while nothing a significant pedagogical change taking place at the time, the pendulum may have swung too far in the direction of speech, and many lecturers are now seeking to increase the effort applied to learning and teaching a command of the written language, and specially to the learning and teaching of reading. 2). Genre Analysis. A genre comprises a class of communicative events, the members of which share some set of communicative purposes. The expert members of the parent discourse community recognize these purposes, and there by constitute the rationale for the genre. This rationale shapes the schematic structure of the discourse and influences and contrains choice of content and style. ESP students can be taught how to recognize (as readers) and mimic (as writers) the "schematic structure" of texts in their chosen discourse communities.

\section{Problems In Learning ESP}

The problems would be viewed in two parts: the first was in form of teaching ESP's problems or lecturer's quality, and the second was students' problems:

\section{Problems in Teaching ESP}

There are five broad problems in teaching English for Specific Purposes (ESP). ${ }^{16}$ a). Teaching pedagogy; In teaching pedagogy, the unclear theoretical basis of ESP is involved whether ESP should be viewed as a tool or a discipline or whether ESP should be considered a practical skill or knowledge capital. Besides, in teaching English for General Purpose sometimes traps the lecturers. In relation to this problem, the authority of the institution should make clear standard of the teaching of ESP in higher education. Moreover, students sometimes are asked only to memorize terminologies in the subject field. It means that lecturer propose how to design tasks to make teaching more meaningful for learners. One of the tasks is a group project by taking advantage of technology. Lecturer further argues that students enjoy interacting with peers and engage willingly in meaningful communication. In addition, aspect of pedagogical competence and its indicators, mastering the characteristic of learners : Lecturers are able to record and use information about the learners' characteristic

${ }^{16}$ Gita Andriani, Problem In Teaching English For Specific Purposes (ESP) In Higher Education,journal of literature language and language teaching, Retrieve juni 12, 2016, http://nobel.uinsby.ac.id/index.php/nobel/article/dow nload/14/11 p.36-38 
to help the learning process. These characteristics are related to the physical, intellectual, social, emotional, moral and sociocultural background, they are : 1). Lecturers can identify the learning characteristics in their class; 2). Lecturers can ensure that all learners have the same opportunity actively participate in learning activities; 3). To provide equal learning opportunities for all learners which have disabilities and different learning abilities, classes can be arranged; 4). It is tried to determine the cause of deviant behavior of learners in order to prevent behavior, such as does not harm other learners, by the lecturer; 5). Lecturers help develop the learners potential and overcome the shortage of learners; 6). Lecturers give attention to learners which have specific physical weaknesses in order to follow the learning activities, so student's are not marginalized (excluded, mocked, minder, etc). ${ }^{17}$

\section{Dominate learning theory and principles of educational learning}

Lecturers are able to establish a wide range of approaches, strategies, methods, and techniques creatively educate learning in accordance with the standards of lecturer competence. Lecturers are able to adjust teaching methods appropriately to the characteristics of learners and motivate them to learn : 1). Lecturers provide an opportunity for learners to master age-appropriate learning materials and learning ability through the learning process and activity; 2). Lecturers always make sure a level of learners' understanding about specific learning materials and adjusting the next learning activities based on the level of understanding; 3). The reason can be explained by the lecturer related to the

Pedagogik Guru, http://web.smp2ppu.sch.id:8888/uploaded/buku/data _4098/pdf/Aspek\%20dan\%20Indikator\%20Kompeten si $\% 20$ Pedagogik $\% 20$ Guru.pdf implementation of the activity/activities done, good and different corresponding to the plan related to successful learning; 4). Lecturers must be able to use various techniques in motivating learner's willingness; 5). Lecturers plan learning activities that are related to another, having regard to the learning propose and the learning process of students have to be planned by lecturer; 6). Lecturers give attention to responses of learners who do not understand the material that is taught and used to improve the design of the next study.

\section{The development of the curriculum}

Lecturers are able to create a syllabus in accordance with the most important goals of curriculum, also lecturer are able to choose, prepare, and organize learning materials appropriate to the learner's need: 1). Lecturers can create a syllabus in accordance with the curriculum; 2). Lecturers designing lesson plans in accordance with the syllabus to discuss specific teaching materials, so that learners can reach the defined basic competencies; 3). Lecturers follow the sequence of learning materials with attention to learning objectives; 4).The materials are chosen by the lecturers which: (1) in accordance with the purpose of learning, (2) accurate and up to date, (3) in accordance with the age and level of learning ability of students, (4) can be implemented in class and (5) in accordance with the context daily lives of learners.

\section{The lecturers}

It is in relation to identity crisis of the lecturers. There is an argument about who should teach ESP, whether it is language lecturers or subject lecturers. Language lecturers sometimes do not understand the material fully, so they difficult in explaining the content of for example reading text. Meanwhile, the subject lecturers sometimes have language problem which will block them in teaching English for Specific Purpose. In addition, Chostelidou states that the success of ESP and CLIL courses depends heavily on the 
quality of lecturers. ${ }^{18}$ It means that success of learning process based on how the quality of the lecturer.

In addition, Problems with ESP lecturers can be classified into six items, they are: 1). Teachers have minimum background knowledge about the subject, business working experiences and awareness of business practices; 2). Knowledge of students' specific language needs; 3). Appropriate authentic teaching materials; 4). Knowledge in teaching methods; 5). Lecturer training programs; 6). Relevant curricula and materials that can reflect or meet the needs of industry. ${ }^{19}$

It means that language lecturers may have neither sufficient specific content knowledge nor awareness of business practice and knowledge of the specific language needs of their students.

\section{The design of the course}

Many and long reading materials must be learned in one semester. The design of the course should be made in such a way to cover this problem; need analysis plays an important role in ESP, in this case. Therefore, the lecturer should conduct needs analysis first before designing the course, in order to know students' goals. Hutchinson and Waters states that considering ESP course design is "fundamentally a matter of asking questioning order to provide a reasoned basis for the subsequent processes of syllabus design, material writing, classroom teaching and evaluation. ${ }^{20}$ Needs analysis include environmental situation, personal information

18 Paul Robertson, The Asian ESP Journal. 2013. Juni 12, 2016, from http://www.asian-esp-journal.com. P.59

${ }^{19}$ Paul Robertson, The Asian ESP Journal. 2013. Juni 12, 2016, from http://www.asian-esp-journal.com. P.60

${ }^{20}$ Mohammad, Journal: English for Specific Purposes World. Juni 12, 2016, from www.espworld.info. Issue 42, Vol. 15, 2014. P.22 about learners, language information about learners, learners' lacks, learners' needs from course, language learning needs, professional information about learners and how to communicate in the target situation.

\section{Students' ability}

Conducting ESP course in earlier semester should be avoided. This will lead to unsuccesful course since the students have not mastered their subject fully, it is better to let the students to cope their subject in English. This is not in accordance with the learners' need which should be considered first. The authority should also consider the time and also the amount of workload of the students. It is not good to have so many materials but there is not available enough time to master all the materials. Thus, it is recommended for the lecturer to have the most important parts of the material which meet the learners need to be designed in ESP course.

\section{Students' needs}

It is very important to analyze students' need before constructing material. ${ }^{21}$ Due to the lack of knowledge of basic language use, the students get problems in ESP which focuses more on content. In line with this, cultural differences which lead to negative transfer sometimes become factor of unsuccessful ESP course. Teaching methodology should be thought by the lecturers in order to be able to help the learners to be successful in ESP course.

\section{Problems with ESP and lecturers}

The success of ESP courses depends heavily on the quality lecturers. ${ }^{22}$ Working within a contemporary knowledge society that has been subject to rapid changes, ESP lecturers have to apply a multiple focus on content and language, and also often need to

\footnotetext{
${ }^{21}$ Nofrika sari, Jurnal Educative Vol. 1 No. 1

22 Paul Robertson, The Asian ESP Journal. 2013.
} Juni 12, 2016, from http://www.asian-esp-journal.com. P.60 
orient them to a new environment and teach unknown, unfamiliar, or emerging genres. Problems with ESP lecturers can be classified into a lack of background knowledge of the subject, business working experiences and awareness of business practices, knowledge of student's specific language needs, appropriate authentic teaching materials, and knowledge in teaching methods, and relevant curricula and materials that can reflect or meet the needs of industry. There are also difficulties caused by marked difference in terms of students level of English and content knowledge, and difficulties in cooperation toward ESP courses and students.

\section{Findings}

This part describes about the data which was gotten in the field in order to answer the formulations of the research, Problems in Reading comprehension in ESP context at Syariah Banking Department. Problems in reading in ESP context are separated into two categories. The first is about quality of lecturers, and the second is students' problem in reading comprehension. The data was based on the students' answers from the questionnaire which had been distributed to the fourth semester students of Syariah Banking Department in IAIN Bukittinggi, and the researcher also interviewed the lecturer to indentify the teaching quality. The data was collected by using interview and questionnaire and which is related to problem in reading comprehension in ESP context. The data about quality of lecturer was gotten by interviewing the English lecturer and was supported by questionnaire of students.

\section{Problem in Lecturer's Quality}

The result of the questionnaire related to quality of lecturer. It was explained in following table:
Table 4.1 : The Result of Teaching Pedagogy (Quality of Lecturers)

\begin{tabular}{|c|c|c|c|c|}
\hline & No & & Freq & ency \\
\hline & Item & & Yes & No \\
\hline & 1. & $\begin{array}{l}\text { Do you think } \\
\text { your English } \\
\text { lecturer has a } \\
\text { good } \\
\text { educational } \\
\text { background to } \\
\text { teach English in } \\
\text { your } \\
\text { department? }\end{array}$ & 84 & - \\
\hline Teaching & 2. & $\begin{array}{l}\text { Do you think } \\
\text { your English } \\
\text { lecturer has a } \\
\text { good experience } \\
\text { which related to } \\
\text { your } \\
\text { department? }\end{array}$ & 84 & - \\
\hline $\begin{array}{c}\text { Pedagogy } \\
\text { (Quality } \\
\text { of } \\
\text { Lecturers) }\end{array}$ & 3. & $\begin{array}{lr}\text { Do you think } \\
\text { your English } \\
\text { lecturer } \\
\begin{array}{l}\text { conclusion } \\
\text { about }\end{array} \\
\text { material? }\end{array}$ & 84 & - \\
\hline & 4. & $\begin{array}{l}\text { Do you think } \\
\text { your English } \\
\text { lecturer } \\
\text { discusses the } \\
\text { material needed } \\
\text { in your } \\
\text { department? }\end{array}$ & 84 & - \\
\hline & 5. & $\begin{array}{l}\text { Do you think } \\
\text { your English } \\
\text { lecturer has } \\
\text { given the } \\
\text { appropriate } \\
\text { material for you? }\end{array}$ & 84 & - \\
\hline & 6. & $\begin{array}{l}\text { Do you think } \\
\text { your English } \\
\text { lecturer has a } \\
\text { specific method } \\
\text { in teaching } \\
\text { English? }\end{array}$ & 81 & 3 \\
\hline & 7. & $\begin{array}{l}\text { Do you think } \\
\text { curriculum } \\
\text { taught in } \\
\text { English learning } \\
\text { refers to the } \\
\text { work } \\
\text { relatives? }\end{array}$ & 84 & - \\
\hline & 8. & $\begin{array}{l}\text { Do you think } \\
\text { English learning } \\
\text { material refers to } \\
\text { the work of } \\
\text { relatives? }\end{array}$ & 83 & 1 \\
\hline
\end{tabular}


The table above shows the result of questionnaire which consist of eight questions that had been answered by eighty four students. The table describes students' entire problem related to quality of lecturer in learning reading in ESP context. There are eight items which includes lack of background knowledge of the subject, business working experiences and awareness of business practices, knowledge of students specific language needs, appropriate authentic teaching materials, knowledge in teaching method and relevant curricula and materials.

\section{Lecturer already Have Good Background Knowledge of the Subject}

Based on the interview, the lecturer gave materials to students then asked to students to read the text. When the students read the materials, the lecturer guided the students in taking meaning of the text. Some of the students asked to students about difficult materials by themselves the lecturer guide students and gave some of the example about the materials. It can be concluded that lecturer have background knowledge about the materials that she taught. It was purposed to provoke the students in reading a text.

\section{Lecturer already Has Business Working Experiences and Awareness of Business Practices}

In teaching learning, the lecturer used authentic materials in teaching reading; lecturer gave material based on business working experiences and awareness of business practices. The materials in reading relevant with their major and refer to practice in the field.

\section{Lecturer already Have Knowledge of Students Specific Language Needs}

Before teaching, the lecturer did need analysis to find students' need in material of learning English and the lecturer also focused on what the goals to be achieved in the development of materials. The lecturer gave attention to respond of students who did not understand the materials she taught.

\section{Appropriate Authentic Teaching Materials}

Based on observation, the English lecturer focused on dominated learning and principles of educational and supported by appropriate authentic teaching materials. In learning process, lecturer used some of authentic material such as journal, articles in teaching reading in the class. In addition, the lecturer used appropriate vocabularies in a text or authentic material. In conclusion, the lecturer had used appropriate authentic materials in teaching.

\section{Knowledge in teaching method}

Based on observation, in learning process the lecturer used method in teaching material like presentation in the class; hopefully the students would not feel bored while learning process. The lecturer used method in teaching reading based on material, if the material short the lecturer used pairs work but if the materials long the lecturer used jigsaw. So, the lecturer had knowledge in choosing appropriate method in teaching.

\section{Relevant curricula and materials}

In this item, the lecturer gave materials based on their need and relevant with their major. The lecturer taught materials not just focused to English but on the text consisted about their major. For example, a text explained macro and micro economic banking.

Meanwhile, the interviewed showed that the lecturer had good quality in teaching reading materials. The lecturer had applied all of items based on the theory. It can be concluded that the lecturer applied all items in every meeting of reading activity.

From interviews conducted does not cause problems in students learning because lecturer have been teaching with good view of lecturer already have good background 
the questionnaire. Seventy seven students answered of the questionnaire. So, most of the students had problem in reading based on use language level.

The second, some of the students in learning process, some of the students difficult to make different topic and genre of in reading text and understand the text. It was proven by calculating of the questionnaire result from the number ten and eleven of the questionnaire. Fifty six students out of eighty four thirty two students had problem in choose topic and genre and twenty eight students did not difficult it.

The third, a small part of the students in learning process, some of the students difficult to comprehension task of in reading. While the lecturer is giving the task or homework, a half students had problem in comprehend task. It was proven by calculating of the questionnaire result from the number twelve of the questionnaire. Thirty nine students out of eighty four students had problem in comprehend their task and forty five students did not problem it.

The fourth, a few of the students in learning process, before the lecturer give the material, a few of the students have negative expectations to the material, and they have felt the material difficult to understand for them. In fact, the lecturer gave material based on their ability. It was proven by calculating of the questionnaire result from the number thirteen of the questionnaire. Twenty eight students out of eighty four students had problem based on negative expectations in comprehending a text and fifty six did not problem it.

The fifth, some of the students few in learning process, the lecture asked to students to read and understand a text. Some have students difficult to take comprehend and meaning text because some of the students still lack vocabularies. Hence, some of students are difficult to understand a text. It was proven by calculating of the questionnaire result from the number fourteen of the questionnaire. Fifty seven students out of eighty four students had problem based on lack vocabularies knowledge and twenty seven did not problem it.

The sixth, most of the student had problem in reading a text based on lack of fluency. There are appears to be an optimum rates of fluency in reading that allows for accurate processing of information. few of the students in learning process, before the lecturer give the material, most of the students lack of fluency to get information the material. it was proven by calculating of the questionnaire result from the number fifteen of the questionnaire. Seventy three students out of eighty four students had problem based on lack of fluency to get information on text and eleven did not problem it.

The seventh, some of the student had problem in reading a text based on lack of familiarity with the subject matter. Their lecture use the authentic material, it is much easier to read with understanding if the reader already possesses some prior knowledge of the topic using movie, journal to build firm background knowledge before students. Some of the student lack of familiarity with the subject matter. It was proven by calculating of the questionnaire result from the number sixteen of the questionnaire. Fifty nine students out of eighty four students had problem based on lack of familiarity with the subject matter and twenty five did not problem it.

The eight, a half of the student had problem in reading a text based on difficulty level of the text (readability). The difficulty level of text is a major factor influencing whether or not material can be read with understanding. A text that is complex in terms of concepts, vocabulary, sentence length and 
structure is difficult for readers to process. A half students had problem to understand if sentence length. It was proven by calculating of the questionnaire result from the number seventeen and eighteen of the questionnaire. Fourth five students out of eighty four students had problem based on difficulty level of the text and thirty nine did not problem it.

The ninth, some of the student had problem in reading a text based on Inadequate use of effective reading strategies. Unlike skilled readers, weaker readers do not approach the interpretation of text strategically. They tend not to know of, or use, strategies that would help them visualize, make connections, reflect, infer, predict, question and summarizes. Some of students had problem to understand if sentence length based on inadequate use of effective reading strategies. It was proven by calculating of the questionnaire result from the number nineteen of the questionnaire. Sixty three students out of eighty four students had problem based on Inadequate use of effective reading strategies and twenty one did not problem it.

The tenth, most of the student had problem in reading a text based on weak verbal reasoning. The ability to understand text, and particularly to go beyond the words on the page in order to make relevant connections among facts and to critique the ideas, reflects the operation of verbal reasoning. To some extent, the ability to reason is determined by an individual's level of intelligence; but guided reading activities in which a lecturer uses effective questioning to challenge students to think more deeply about the text they are reading are helpful in developing their ability to reason from the information given. Deliberately guiding students to make connections between new information in text and their existing bank of knowledge is beneficial. Most of students had problem based on weak verbal reasoning. It was proven by calculating of the questionnaire result from the number twenty of the questionnaire. Sixty students out of eighty four students had problem based on weak verbal reasoning and twenty four did not problem it.

The eleventh, most of the student had problem in reading a text based on problems with processing information. In order to maintain the meaning of text as the sentences and paragraphs accumulate, a reader has to be able to keep relevant information within working memory and make necessary connections between ideas. Limited working memory is sometimes suggested as a causal factor in poor comprehension. It is known that individuals differ in their workingmemory capacity, with some able to process and accommodate much more information than others. Most of students had problem based on problems with processing information It was proven by calculating of the questionnaire result from the number twenty one of the questionnaire. Fourth seven students out of eighty four students had problem based on problems with processing information and thirty seven did not problem it.

The last, a few of the student had problem in reading a text based on problems in recalling information after reading. Recall is dependent partly upon factors such as vividness and relevance of the information in the text; but it is also dependent upon a student giving adequate attention to the reading task and knowing that it is important to remember details. Recall is strongest when readers connect new information in the text to their previous knowledge and experience, and when they rehearse key points from the text. A few of students had problem based on problems in recalling information after reading. It was proven by calculating of the questionnaire result from the number twenty two of the questionnaire. Twenty nine 
students out of eighty four students had problem based on problems with processing information and fifty five did not problem it.

Based on the explanation of 22 items above, it is known that kinds of problem in reading in ESP by the fourth semester students of Syariah Banking Department at the academic year 2017/2018 IAIN Bukittinggi were teaching pedagogy (Quality of Lecturers), students' problem in reading, but not all of the students had problem in items in teaching pedagogy (Quality of Lecturers), students' problem in reading only some of them had problem about it.

\section{Conclusion}

Based on the finding of the research about what problems found in reading comprehension in ESP context by the fourth semester students of Syariah Banking Department, it can be concluded that students' problem in reading in ESP context by the students based on Teaching pedagogic (Quality of lecturer) and Problems in reading, they are: 1). Based on Teaching pedagogic (Quality of lecturer), the English lecturer in teaching material in class had applied the indicators in pedagogic teaching (quality of lecturer) focus on dominated learning theory to improve lecturer's teaching ability. The teaching in the class was good. It can be concluded that all of students had no problem based on indicators in pedagogic teaching (quality of lecturer); 2). It is known that the most problem in reading in ESP context by the fourth semester students of Islamic banking at 2017/2018 academic year IAIN Bukittinggi were Lack of fluency, Use of language level, Inadequate use of effective reading strategies. It can be concluded that the highest problems faced by students were Lack of fluency, Use of language level, Inadequate use of effective reading strategies Next, Topic and genre, Limited vocabulary knowledge, less of familiarity with the subject matter,
Difficulty level of the text (readability), Weak verbal reasoning and then, Problems with processing information. Last, comprehension task and negative Expectations, problems in recalling information after reading.

\section{References}

Alderson J Charles, Assesing the Nature of Reading

Carrell and Connor in David Nunan, Practical English Language Teaching, Mc Graw Hill, 2003

Carrell,C.N and N.P Breen. 1979. Evaluating and designing language teaching materials'.Practical papers in English languages education. Vol 2. university of Lancaster.

Floris and Divina, TEFLIN Journal, Volume 20, Number 1, February 2009.

Janette K.Klinger, Sharon Vaughn, and Alison Boardman, Teaching Reading Comprehension to Students with Learning Difficult,

McWhorter, K.T. 2002. Efficient and Flexible Reading (sixth edition). New York: R.R. Donnelley and Sons.

Mohammad, Journal: English for Specific Purposes World. Retrieve juni 12, 2016, from www.espworld.info. Issue 42, Vol. 15, 2014

Nunan David, Practical English Language Teaching, Mc Graw Hill, 2003

Nunan David, Practical English Language Teaching: Young Learners

Paul Robertson, The Asian ESP Journal. 2013. Retrieve juni 12, 2016, from http://www.asian-esp-journal.com

Sari, Nofrika. Instructional English Reading Materials used by Teacher at grade X SMKN 1 Pangkalan KotoBaru 50 Kota Regency, Journal Educative: Journal of Education Studies, Vol. 1, No.1 Januari-Juni 2016 